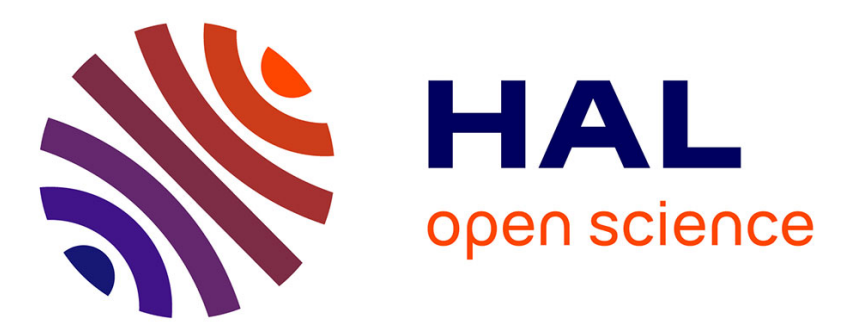

\title{
Archaeobotanical investigations at the earliest horse herder site of Botai in Kazakhstan
}

Giedre Motuzaite Matuzeviciute, G E Lightfoot, X. Liu, Jérémy Jacob, A. K Outram, V. F Zaibert, S. Zakharov, M. K. Jones

\section{> To cite this version:}

Giedre Motuzaite Matuzeviciute, G E Lightfoot, X. Liu, Jérémy Jacob, A. K Outram, et al.. Archaeobotanical investigations at the earliest horse herder site of Botai in Kazakhstan. Archaeological and Anthropological Sciences, 2019, 10.1007/s12520-019-00924-2 . hal-02347098

\section{HAL Id: hal-02347098 \\ https://hal.science/hal-02347098}

Submitted on 5 Nov 2019

HAL is a multi-disciplinary open access archive for the deposit and dissemination of scientific research documents, whether they are published or not. The documents may come from teaching and research institutions in France or abroad, or from public or private research centers.
L'archive ouverte pluridisciplinaire HAL, est destinée au dépôt et à la diffusion de documents scientifiques de niveau recherche, publiés ou non, émanant des établissements d'enseignement et de recherche français ou étrangers, des laboratoires publics ou privés. 


\title{
Archaeobotanical investigations at the earliest horse herder site of Botai in Kazakhstan
}

\author{
Giedre Motuzaite Matuzeviciute ${ }^{1}$, G. E. Lightfoot ${ }^{2}$, X. Liu $^{3}$, J. Jacob ${ }^{4}$, A. K. Outram ${ }^{5}$, V. F. Zaibert ${ }^{6}$, S. Zakharov ${ }^{7}$, M. K. Jones ${ }^{8}$ \\ ${ }^{1}$ The Lithuanian Institute of History, Kražių g. 5, 01108 Vilnius, Lithuania \\ ${ }^{2}$ McDonald Institute for Archaeological Research, University of Cambridge, Downing Street, Cambridge CB2 3ER, UK \\ ${ }^{3}$ Department of Anthropology, Washington University in St. Louis, One Brookings Drive, St. Louis, MO 63130, USA \\ ${ }^{4}$ Laboratoire des Sciences du Climat et de l'Environnement, UMR 8212 CEA-CNRS-UVSQ, Université Paris-Saclay, Gif-sur-Yvette, France \\ ${ }^{5}$ Department of Archaeology, University of Exeter, Laver Building, North Park Road, Streatham Campus, Exeter EX4 4QE, UK \\ ${ }^{6}$ al-Farabi Kazakh National University, Prospect al-Farabi 71, Almaty 050040, Kazakhstan \\ ${ }^{7}$ Archaeological Expertise LLC, Baikadamova 10-2, Almaty, Kazakhstan \\ ${ }^{8}$ Department of Archaeology and Anthropology, University of Cambridge, Downing Street, Cambridge CB2 3DZ, UK
}

\begin{abstract}
This paper presents new radiocarbon dates and the results of the first archaeobotanical investigations at Eneolithic Botai site, for the first time aiming to explore the plant food component in the diet of Botai population and if the inhabitants of the Botai were a part of an early crop food exchange network. Our excavation of a hut circle and associated radiocarbon dating placed its occupation within a date range commencing around 3550 and $3030 \mathrm{cal} \mathrm{BC}$ and ending between 3080 and $2670 \mathrm{cal} \mathrm{BC}$. A separate feature (likely a stove or kiln), excavated in test trench E, would seem to be younger, around $2000 \mathrm{cal} \mathrm{BC}$. The dating of the site thus also indicates a previously unknown later occupation at Botai, opening further discussions on human subsistence and interaction as well as horse management in northern Eurasia from the Eneolithic to the Bronze Age. The archaeobotanical results, derived from systematic sampling and analysis of macrobotanical remains, plant phytoliths, and molecular biomarker analysis show that the Botai populations were not part of any wider crop network. The relatively small seed count would indicate that plant foods did not constitute a substantial component of economic life. On the other hand, the presence of miliacin could suggest possible millet cultivation or consumption in this region at some point in the past, possibly after the main occupation period of Botai.
\end{abstract}

Keywords Eurasiansteppe, Agriculture, Miliacin, Archaeobotany, Eneolithic 


\section{Introduction}

The spread of crops from their centres of origin to new territories is often associated with the establishment of new food networks and with major social changes, such as population growth and increasing sedentism. The archaeobotanical record indicates that at different times in the past, East Asian crops (e.g., millet and buckwheat) began to be cultivated in Europe, and the cultivation of southwest Asian crops (e.g., wheat and barley) was established in China (e.g., Betts et al. 2013; Boivin et al. 2012; Filipović et al. 2018; Jones et al. 2011; Jones 2004; Liu et al. 2019; Long et al. 2018; Miller et al. 2016; Motuzaite Matuzeviciute et al. 2013a). The eastwest and west-east spread of these crops was a long-term process that was established through a dense interaction network of Central Asian pastoralists (e.g., Frachetti et al. 2017).

The Eneolithic site of Botai dated to about 3700-3000 cal BC is located in Akmola Province, northern Kazakhstan (Fig. 1) (Anthony 2007). The site is situated in the current foreststeppe climatic ecotone along the Iman-Burluk River, ca. $120 \mathrm{~km}$ from Kokshetav city (Fig. 2). The site was first recognized by professional archaeologists in 1980 (Zaibert et al. 2007; Zaibert 1981). Archaeological excavations were undertaken by V. Zaibert in 1980 and most subsequent years. Since the discovery of Botai, over 20 contemporaneous sites have been identified in the Ural-Irtys interfluve. Almost all of these sites are located on high banks of small steppe rivers on elevated granite bedrock that could support pine and birch tree forest (Kislenko and Tatarintseva 1999). Due to similarities in their economy and material culture, all of these sites have been attributed to the Botai culture (also called the Botai-Tersek culture). The large inventory of stone, clay and bone artefacts, cult amulets, and permanent houses show the complex economic structure of Botai culture sites (Zaibert 1993). No artefacts clearly attributed to crop processing or cultivation have yet been identified at Botai culture sites.

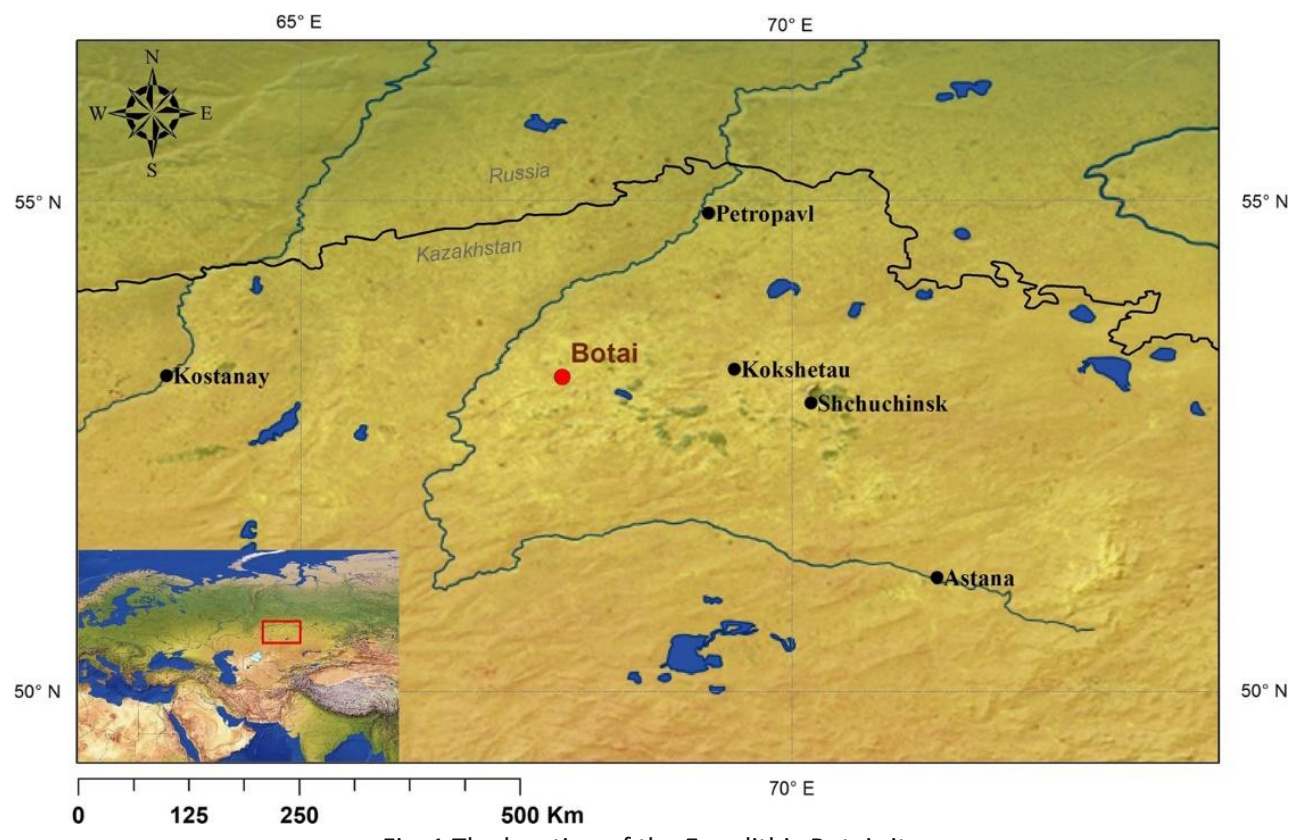

Fig. 1 The location of the Eneolithic Botai site

From the west to east, recent studies have clarified the chronology of crop movements and proposed that the eastern dispersals of wheat and barley might have been distinct in time and space (Lister et al. 2018; Liu et al. 2017; Liu et al. 2016). From the east to west, it has been argued that the arrival of the domesticated horse in southeast Europe coincides with the earliest arrival of Chinese millet, both of which could have spread via the steppe corridor (Valamoti 2013). The ecological/biological characteristics of eastern cereals (broomcorn and foxtail millet and buckwheat), such as short growing season and adaptability to dry steppe environments, may have facilitated the early western movements across 
the Eurasian steppe (Janik 2002; Jones 2004; Jones et al. 2016; Jones et al. 2011). However, the exact timing and possible geographical pathways of Chinese crop dispersals into Europe still remain the centre of discussion (Hunt et al. 2008; Liu et al. 2018; Motuzaite Matuzeviciute et al. 2015; Motuzaite Matuzeviciute et al. 2013a; Motuzaite Matuzeviciute et al. 2009).

Both the chronological and the geographical positions of Botai, which is located in northern Kazakhstan (Fig. 1), render it an ideal focus of enquiry in understanding food dispersal processes across Eurasia. This site provides the earliest evidence of horse management, which could have facilitated the establishment and expansion of food networks across Eurasia (Outram et al. 2009). Little is known, however, about the role of plant foods in the economy of Botai and whether or not domesticated plants were grown and/or consumed at the site. We therefore embarked upon a search for plant food remains at Botai conducting a small excavation which employed achaeobotanical research techniques at macrobotanical, microbotanical, and molecular levels.

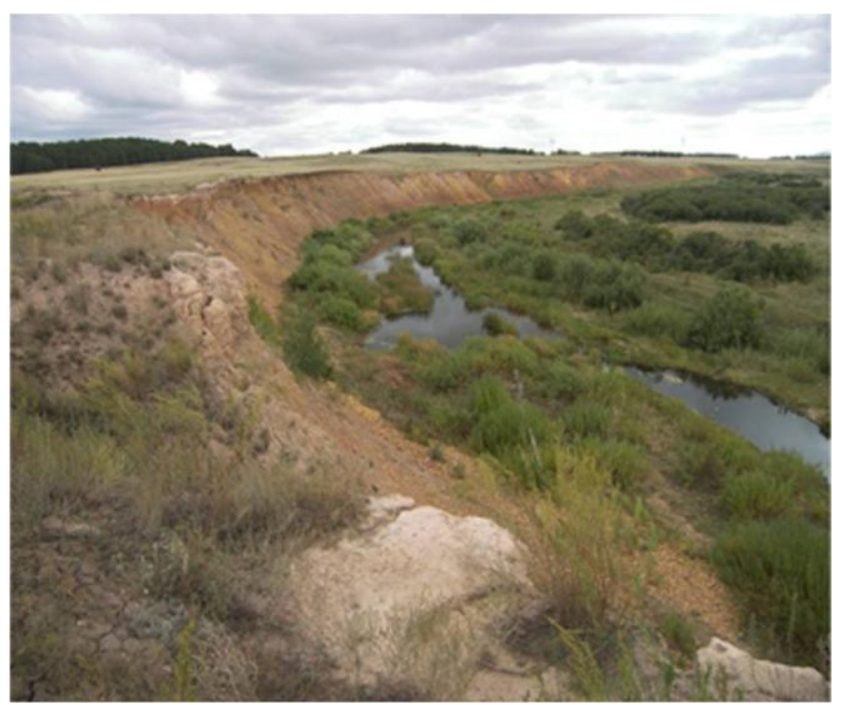

Fig. 2 The surrounding forest-steppe landscape of the Botai site

\section{Site background}

The Botai site extends over $15 \mathrm{ha}$. It comprises a large number of semi-dugout houses surrounded by thousands of pit structures. The location of over 80 houses is visible on the surface of the site and it is estimated that over 250 houses stood in the Botai settlement in total (Zaibert 1985). Archaeologists have inferred that the Botai houses were subterranean with clinker built round walls covered with daub, with a turf roof supported only by the walls (Zaibert et al. 1983). The diet of the Botai inhabitants has so far only been studied from the perspective of animal resources. The excavations have resulted in the discovery of thousands of horse bones, which constitute $99 \%$ of the skeletal remains (Benecke and Von Den Driesch 2003; Olsen 2000). The only other domestic species found at Botai is dog-no sheep, goat, or cattle (southwest Asian domesticates) have been recovered (Outram et al. 2009). This unusual zooarchaeological assemblage has attracted specialists from all over the world to study the question of horse domestication (Anthony 1997; Benecke and Von Den Driesch 2003; Olsen 2003; Outram et al. 2009; Levine 1999). Outram et al. (2009) have presented the earliest evidence for horse harnessing and milking at the Botai site, dated to Eneolithic period (mid. 4th millennium $\mathrm{BC})$. Recent aDNA research on Botai horses has shown them to be ancestral to Przewalski horses, which currently live in Mongolia, and that modern domestic horses belong to a separate clade domesticated elsewhere, possibly in western 
Eurasia (Gaunitz et al. 2018). Genetic research on humans found at Botai has shown them to descend from Ice Age hunter-gatherer populations that form a cline stretching from the Urals to Baikal during the Eneolithic and Early Bronze Age. The analysed Botai individuals have no admixture with Yamnaya populations in the west (de Barros Damgaard et al. 2018). It appears that boththe Botai people and their horseswerereplaced inthe region by later waves of migration.

Despite the excellent studies ofthe Botaizooarchaeological assemblage, no studies of the plant component of the economy of the Botai culture have been carried out. The archaeobotanical data presented here are the first study of the corresponding plant evidence from Botai site.

\section{Review of previous archaeobotanical research in Central Asia}

The timing, means, and pathways of pioneer crop dispersal across Eurasia have attracted scholarly interest for some time. Recent studies suggest that wheat reached China following possibly steppe route by 3000 BC (Long et al. 2018), while barley reached China via multiple routes by 2000 BC (Lister et al. 2018; Liu et al. 2017). At a similar time, the Chinese domesticate broomcorn millet reached Europe (Motuzaite Matuzeviciute et al. 2013a; Liu et al. 2018). The possible presence of broomcorn millet seen in more northern latitudes suggests that it may be linked with populations from the steppe (Kučera et al. 2019). However, archeobotanical evidence from the northern regions of the Eurasian steppe is very limited. While past vegetation has been reconstructed from pollen cores (Tarasov et al. 2012), reports of systematic flotation are rare, especially for the Eneolithic period, in Central Asia. In the southern Ural region, systematic flotation has been carried out at Yamnaya Culture sites during the Samara Valley Project where no domesticated crop species were recovered (Anthony et al. 2005). The prehistoric inhabitants of this region may have consumed wild plant seeds such as Chenopodium (goosefoot), Amaranthus, Brassica, Eragrostis, Polygonum, and Galium (Popova 2006; Anthony et al. 2005).

Attempts to find macrobotanical evidence of cultivated cereals were also carried out at the metallurgical centres of the Sintashta culture (Middle Bronze Age), such as Kamennyi Ambar and Olgino (Stobbe and Joop Kalis 2012) both located in the south eastern regions of the Ural Mountains. The flotation here in the Trans-Ural region again reported the presence of only wild plant species, dominated by Chenopodium sp. (Rühl et al. 2015; Stobbe and Joop Kalis 2012). The earliest cereal macroremains in this region, consisting of wheat, barley, and millets, are dated to the Final Bronze Age (Andronovo, 2000-900 BC) (Anthony 2007; Lebedeva 2005).

For northern Kazakhstan, a few charred wheat grains have been reported from a Middle Bronze Age votive place next to the Alekseev settlement (Krivtsova-Grakova 1947). However, these grains have recently been re-dated to the Early Iron Age (Shishlina et al. 2018). From the available archaeobotanical evidence, cultivated plants in southern Siberia and central Kazakhstan are reported only from the first millennium BC (Ryabogina and Ivanov 2011; Spengler et al. 2016), whereas stable isotope data show $\mathrm{C}_{4}$ plant consumption at northern and central regions of Eurasian steppe during the late second to first millennium BC, suggesting a millet contribution to diet in this region (Ananyevskaya et al. 2017; Motuzaite Matuzeviciute et al. 2015; Murphy et al. 2013; Svyatko et al. 2013).

Currently, the majority of the well-dated evidence for arable agriculture in Central Asia has been reported from piedmont sites of the Inner Asian Mountain Corridor and dated to the Early Bronze Age period (mid third millennium BC) (Doumani et al. 2015; Hermes et al. 2019; Spengler et al. 2014a, b). The earliest macrobotanical evidence of wheat (Triticum cf. aestivum) and broomcorn millet (Panicum miliaceum) was reported from the mountainous regions of southeastern Kazakhstan, where these two crops were found in human burials at Begash and dated to ca. $2200 \mathrm{cal}$ BC (Frachetti et al. 2010).

From the later second millennium BC, macroremains of domesticated plant species are reported only from south eastern regions of Central Asia, among which are the well-studied Tuzusai, Tasbas, Kyzylbulak, or Mukri sites, located in the Semirech'ye region of south-eastern Kazakhstan (Chang et al. 2003; Doumani et al. 2015; Rosen 2001; Rosen et al. 2000; Spengler et al. 2014a, b). The analysis of phytoliths and macroremains at those sites showed that the inhabitants 
living in the mountain piedmont of Central Asia were growing broomcorn millet, peas, wheat, and barley (Rosen et al. 2000; Spengler et al. 2013).

\section{Excavated contexts}

The extensive magnetometer survey undertaken by Alan Outram and students from the University of Exeter allowed various features to be selected for excavation (Gaunitz et al. 2018). The excavated features included an entire house and its associated pits (Zone A) (Fig. 3), an outlying pit complex (Zone B), a multiple-phase stove/kiln (test trench E) (Fig. 4), and a palaeosoil exposed by the eroding riverbank (test trench D). The largest zone, Zone A, corresponded to a hut circle with pits in the central part of the hut. Zone B represents excavations at another pit house that contained an internal pit sampled for archaeobotanical research. Test trench E contains a multiple-phase feature that likely represents a stove or kiln with the clay walls, located on the edge of the settlement. There was a series of burnt deposits inside of the feature, which seemed to provide another good opportunity to find plant remains at Botai. In the case of trench D, through a suspected soil profile, the excavation utilised a river-cut section and aimed to expose a vertical section through the soil profile, without horizontal exploration. The buried soil in the section had previously been interpreted as similar to cultivated or trampled soils (French 2003).

\section{Sample collection}

The search for early crops involves a range of methodologies, a number of which we applied at Botai. The principal methodology was flotation for macrofossils, with two subsidiary methodologies, sampling for phytoliths and biomarkers.

\section{Macrobotany}

The most widespread archaeological form of plant evidence is charred macrofossils, fragments that have been exposed to a fire and reduced, largely to elemental carbon, but which retain enough shape and morphological detail to allow fairly precise identification, through visual, low-power microscopy. They contain enough air pockets to float on water and are typically separated by flotation.

We designed and built a flotation machine that used a small pump to draw river water, filtered through a 250- $\mu \mathrm{m}$ mesh, into an overflow unit (Fig. 5). Sediment samples were suspended in a 2000- $\mu \mathrm{m}$ mesh to catch the heavy fraction, with the overflow feeding into a 500- $\mu \mathrm{m}$ mesh to catch the light fraction. In this manner, sediment from 43 separate features was floated, often subdivided into several contexts (50 in total). In total, 2006 I of sediments was floated from Botai. Our default sediment sample size was $40 \mathrm{I}$.

\section{Phytolith sampling}

Bulk samples were collected during excavation and stored in sealed plastic bags. Eighteen contexts were chosen for phytolith sampling. The context of the phytolith samples largely coincided with those chosenfor macrobotanical/flotation sampling, which included the pits, the fireplace, and the house floor inside of the house in Zone A and from the external stove/kiln at the test trench E. In addition, three phytolith samples were taken from the section of an eroded riverbank, away from the inhabited area (test trench D). Sample blocks were taken from the buried soil and from the sediments above and below it.

\section{Biomarker sampling}

One kilogram of sediment was collected from a range of features during excavation for biomarker analysis, specifically miliacin, a lipid found in broomcorn millet (Panicum miliaceum), but not in foxtail millet (Setaria italica), analysis. These features included pits, a floor, the river-cut section (test trench D), and the stove/kiln in test trench $\mathrm{E}$. 

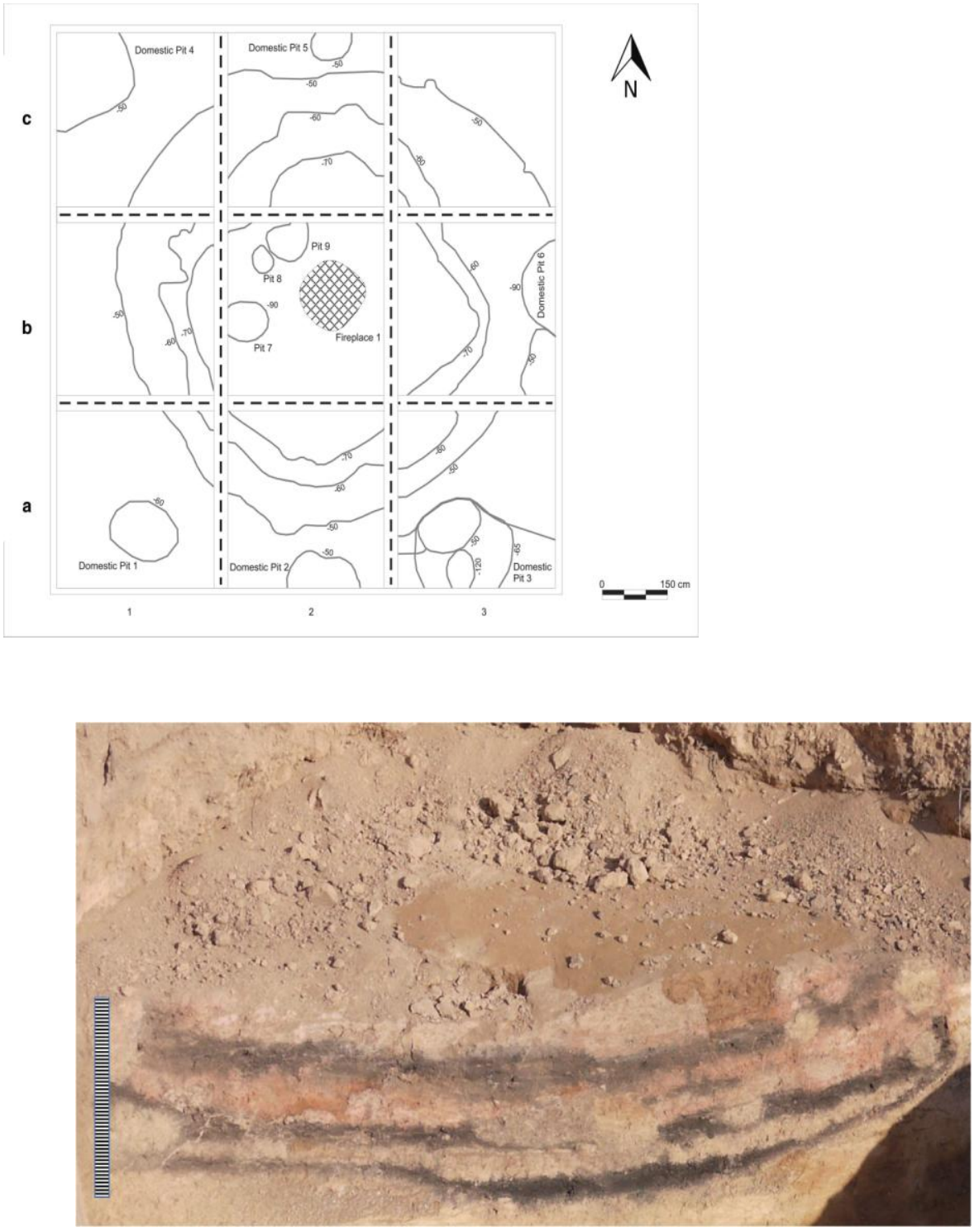

Fig. 3 The plan and the contexts of the excavated pit house at the Botai site 
Fig. 4 The base of a stove/kiln in the test trench E dated to ca. $2000 \mathrm{BC}$ and located on the edge of Botai site. The bar mark is ca. $20 \mathrm{~cm}$ in length

Fig. 5 Archaeobotanical sample flotation at the Botai site. In total, 2006 I of sediments was floated

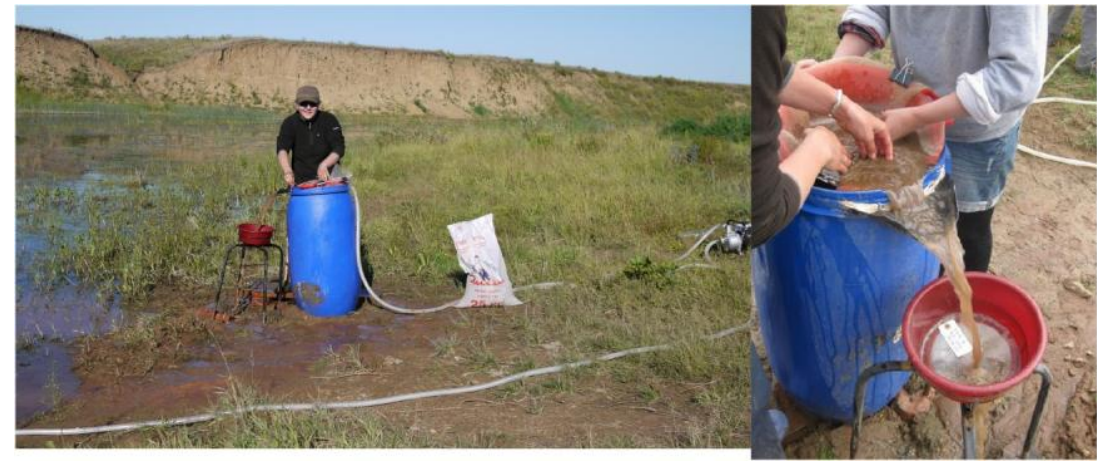




\section{Laboratory analysis}

\section{Radiocarbon dating of floated material}

The radiocarbon dating of the sequence at Botai focused on features inside the house (Zone A) and in test trench $E$. Twenty-two samples were radiocarbon dated at the Radiocarbon Accelerator Laboratory (BA) at Peking University, Beijing. Where possible, samplingfocused on vascular tissue, twigs, and tree bark rather than wood charcoal, with the aim of avoiding the problem of Bold wood^ ${ }^{\wedge}$. Sixteen of the analysed samples returned results. The results were calibrated using OxCal version 4.2.4 (Bronk Ramsey 2013) using the IntCal13 atmospheric curve (Reimer et al. 2013). Date ranges are reported as $95 \%$ posterior probabilities. In order to increase the accuracy and precision of the chronological sequence, the dates were modelled using the Bayesian functions in OxCal. Chi-squared and outlier analysis was performed in OxCal (Bronk Ramsey 2009) (see SOM 1 for more details).

\section{Archaeobotany}

Sorting and identification of archaeobotanical material took place at the University of Cambridge in the George PittRivers Laboratory for Bioarchaeology, University of Cambridge. Each flotation sample was sorted individually by selecting and counting all charred grains within the sample. All of the retrieved flotation samples were sorted and analysed.

The macrobotanical samples were identified using a lowpower stereomicroscope $(\times 6-\times 40)$, the reference collections available at the George Pitt-Rivers Laboratory for Bioarchaeology. The Digital Seed Atlas of the Netherlands (Cappers et al. 2006) and the Atlas of Seed (volumes 2-4) (Anderberg 1994; Berggren 1994) were also used for references. We identified most of the carbonised plant remains to genus level.

\section{Phytoliths}

Phytolith extraction was carried out twice, following two different extraction protocols at the George Pitt-Rivers laboratory, University of Cambridge. The main reason for using two different protocols on the same samples was to compare two different methodologies and to determine the best methodology for phytolith extraction given Botai's preservation conditions.

For the first protocol, $5 \mathrm{~g}$ of sediment samples was dried in an oven at $50{ }^{\circ} \mathrm{C}$ and was then treated with $25 \mathrm{ml}$ of $7 \%$ solution of hydrochloric acid $(\mathrm{HCl})$. The samples were placed on a hotplate at $40^{\circ} \mathrm{C}$ until the liquid evaporated to $5 \mathrm{ml}$ and the reaction had stopped. The residues left after dissolution of carbonates were rinsed 3 times with distilled water, centrifuging the samples at $1500 \mathrm{rpm}$ for $3 \mathrm{~min}$ between rinses. Fifty millilitres of sodium hexametaphosphate $\left(\left(\mathrm{NaPO}_{3}\right)_{6}\right)$ was added and left for $8 \mathrm{~h}$, and then samples were rinsed three times, centrifuging the samples at $1500 \mathrm{rpm}$ for $3 \mathrm{~min}$ between rinses. Twenty-five millilitres of hydrogen peroxide was added to the samples and they were kept in an oven for $8 \mathrm{~h}$ at $50{ }^{\circ} \mathrm{C}$. The samples were then rinsed 3 times with distilled water, centrifuging the samples at $1500 \mathrm{rpm}$ for $3 \mathrm{~min}$ between rinses. When the samples were dried until no weight loss occurred, $25 \mathrm{ml}$ of sodium polytungstate $\left(\mathrm{Na}_{6}\left(\mathrm{H}_{2} \mathrm{~W}_{12} \mathrm{O}_{40}\right) \mathrm{H}_{2}\right)$ was added with a density of $2.35 \mathrm{~g} / \mathrm{ml}$, then centrifuged at $1500 \mathrm{rpm}$ for $3 \mathrm{~min}$. Then the phytoliths were transferred to the new tube, $50 \mathrm{ml}$ distilled water added and centrifuged for $5 \mathrm{~min}$ at $2000 \mathrm{rpm}$ for 4 times. The samples were dried and the residue mounted on slides using Entellan New (Merck) and scanned by optical microscopy at $\times 400$ and $\times 600$ magnification. The second protocol followed similar phytolith extraction procedures, but slightly weaker chemicals as well as smaller volumes of reagents were used, and centrifuging regimes were shorter and at lower rmp. Four grams of dried sediment was placed in a $100-\mathrm{ml}$ beaker and topped up to $25 \mathrm{ml}$ with a $5 \%$ solution of hydrochloric acid $(\mathrm{HCl})$. Instead of $25 \mathrm{ml}$ as was done in the first extraction procedure, $15 \mathrm{ml}$ of $33 \%$ volume of hydrogen peroxide $\left(\mathrm{H}_{2} \mathrm{O}_{2}\right)$ was added to the samples and heated on a hot plate at $40^{\circ} \mathrm{C}$. Also, instead of using $25 \mathrm{ml}$, only

$15 \mathrm{ml}$ of sodium polytungstate $\left(\mathrm{Na}_{6}\left(\mathrm{H}_{2} \mathrm{~W}_{12} \mathrm{O}_{40}\right) \mathrm{H}_{2}\right)$ was added tothe sample. With this protocol, phytoliths were rinsed from sodium polytungstate three times running the centrifuge for 3 min instead of 5 at $2000 \mathrm{rpm}$. 


\section{Biomarker analysis}

An aliquot (ca. $2 \mathrm{~g}$ ) ofeach sample was extracted by automatic solvent extraction with a Dionex ${ }^{\circledR}$ ASE 200, using a mixture of $\mathrm{CH}_{2} \mathrm{Cl}_{2}: \mathrm{MeOH}(9: 1 \mathrm{v} / \mathrm{v})$. The total lipid extract was separated into neutral, acidic, and polar fractions by solid-phase extraction realised on aminopropyl-bonded silica, as described by Jacob et al. (2005). The neutral lipid fraction was further separated into aliphatics, aromatics, ethers and esters, acetates, ketones, and alcohols, by flash chromatography on a Pasteur pipette filled with activated silica $\left(24 \mathrm{~h}\right.$ at $120{ }^{\circ} \mathrm{C}$, then deactivated with $5 \% \mathrm{H}_{2} \mathrm{O}$ ), using a sequence of solvents of increasing polarity. After addition of $5 \alpha$-cholestane as a quantitation standard, the ethers-esters fraction (that contains miliacin fraction) was analysed by GC/MS on a Trace GC Ultra gas chromatograph coupled to a TSQ Quantum XLS mass spectrometer equipped with an AS 3000 autosampler (both from Thermo-Scientific, Bremen, Germany). The GC was fitted with a TG-5 MS capillary column (60 m,

$0.25 \mathrm{~mm}$, i.e., $0.25 \mu \mathrm{m}$ film thickness; Thermo, Bellefonte, PA, USA). The temperature of the column was held at $40^{\circ} \mathrm{C}$ for $1 \mathrm{~min}$ and then increased from 40 to $120{ }^{\circ} \mathrm{C}$ at $30{ }^{\circ} \mathrm{C} \mathrm{min}^{-1}$ and then from 120 to $300{ }^{\circ} \mathrm{C}$ at $3{ }^{\circ} \mathrm{C} \mathrm{min}{ }^{-1}$, with a final isothermal hold at $300{ }^{\circ} \mathrm{C}$ for $70 \mathrm{~min}$. The sample was dissolved in toluene, and $2 \mu \mathrm{l}$ was injected in splitless mode at 280 ${ }^{\circ} \mathrm{C}$. The carrier gas was helium at a flow rate of $1.0 \mathrm{ml} \mathrm{min}^{-1}$. The mass spectrometer was operated in the electron ionization mode at $70 \mathrm{eV}$ and scanned from $\mathrm{m} / \mathrm{z} 50$ to 600 . Miliacin was identified using an authentic standard. Due to low levels, miliacin was quantified by comparing the area of its peak on the $\mathrm{m} / \mathrm{z} 189+204+218$ ion specific chromatogram with that of $5 \alpha$-cholestane on the total ion current (TIC) after applying a correction factor for the contribution of fragments $\mathrm{m} / \mathrm{z} 189+204+218$ to the entire mass spectrum of miliacin. Concentrations in miliacin are expressed as nanograms per gram sediment. 


\section{Results}

\section{Radiocarbon dating}

House (Zone A)

A total of 13 radiocarbon dates were obtained from inside the house, mostly relating to the central fireplace and the floors above and below it, as well as the lowest floor layer of the house. The dates were first calibrated individually (Table 1); however, when one considers these dates in conjunction with the stratigraphic information, it is clear that the sequence of dates is problematic, with several dates seemingly out of sequence. The dates were therefore modelled using OxCal, which allowed for outlying dates to be statistically identified and removed, and dates from samples from the same context to be combined (see SOM 1 for a full description of the statistical analysis and modelling). Using this, Bayesian approach suggests that the main period of occupation started between 3550 and $3030 \mathrm{cal} \mathrm{BC}$, and ended between 3080 and 2670 cal BC (Fig. 6a; SOM 1).

Phase A1 corresponds to the earliest fill of the Zone A Test trench E house, directly above the subsoil cut. We can associate Phase A1 with circa $3500 \mathrm{BC}$.

Phase A2 corresponds to a significant part of the internal stratigraphy of the pit hollow, and includes a significant quantity of contained cultural evidence. This phase spans a significant period during the second half of the fourth millennium BC.

Phase A3 corresponds to the abandonment of the houses such that the clay walls collapse into the house area; the phase corresponds to the evidence contained within the thick deposit resulting from the collapse of those walls. This event is situated either at the end of the fourth millennium BC, or the beginning of the third.

\section{Test trench $\mathrm{E}$}

Three samples were sent for dating from test trench $E$, which likely represents a kiln on the edge of the Botai prehistoric village. The three dates are taken from three different layers in the feature and calibrated separately (Fig. 6b). This sets a date range of 2290 to $1530 \mathrm{cal} \mathrm{BC}$. Here we suspect that the labelling of the samples got mixed up resulting the oldest date to become the uppermost layer and the youngest date to become the lowest layer.

The parsimonious interpretation of these dates is that they indicate an episode significantly younger than the Zone $\mathrm{A}$ house. 
Table 1 All AMS ${ }^{14} \mathrm{C}$ dates (individually calibrated, with outliers underlined) received from the house and an external kiln/ stove of the Botai site. The OxCal 4.2.4 calibration was used (Bronk Ramsey et al. 2013; Reimer et al. 2013)

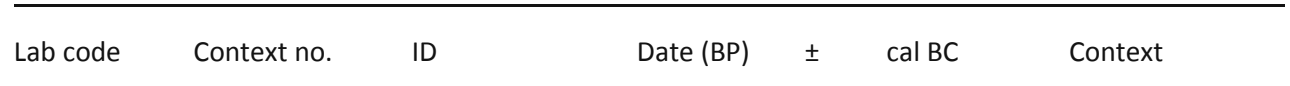

\begin{tabular}{|c|c|c|c|c|c|c|c|c|}
\hline \multirow{2}{*}{\multicolumn{2}{|c|}{$\begin{array}{l}\text { Fig. } 6 \text { The }{ }_{\text {BA121467 }} \\
\text { statistics plots }\end{array}$}} & & & & & & & \multirow{3}{*}{$\begin{array}{l}\text { Bayesian } \\
\text { of a pit house } \\
\text { chronological }\end{array}$} \\
\hline & & B2/0095 & Tree branch & 4595 & 35 & $3511-3119$ & Inside the house & \\
\hline \multirow{2}{*}{\multicolumn{2}{|c|}{$\begin{array}{ll}\text { indicating } & a^{\text {BA121469 }} \\
\text { probability } & \text { of BA121466 }\end{array}$}} & B2/0058 & Wood charcoal & 4490 & 25 & $3341-3094$ & Inside the house & \\
\hline & & $\mathrm{C} 2 / 0067$ & Parenchyma & 4440 & 25 & $3329-2936$ & Inside the house & main \\
\hline \multirow{4}{*}{$\begin{array}{l}\text { occupation } \\
\text { Radiocarbon } \\
\text { distributions of } \\
\text { (external } \\
\text { the edge of }\end{array}$} & BA120864 & B2/0059 & Twig & 4465 & 30 & $3338-3024$ & Inside the house & \multirow{4}{*}{$\begin{array}{l}\text { periods }(\mathrm{A}) \text {. } \\
\text { age } \\
\text { a test trench } \mathrm{E} \\
\text { kiln/stove) on } \\
\text { Botai site (B) }\end{array}$} \\
\hline & BA120872 & B2/0059 & Tree bark & 4450 & 30 & $3336-2944$ & Inside the house & \\
\hline & BA120858 & B2/0081 & Twig & 4475 & 35 & $3341-3027$ & Inside the house & \\
\hline & a BA120857 & B2/0024 & Twig & 4530 & 35 & 3363-3101 & Inside the house & \\
\hline & BA121465 & B2/0035 & Wood charcoal & 4385 & 25 & 3090-2917 & Inside the house & \\
\hline & BA121471 & B2/0035 & Wood charcoal & 4375 & 25 & $3087-2912$ & Inside the house & \\
\hline & BA121470 & B2/0026 & Wood charcoal & 4355 & 25 & $3078-2906$ & Inside the house & \\
\hline & BA121468 & B2/0057 & Wood charcoal & 4325 & 25 & $3013-2893$ & Inside the house & \\
\hline & BA120865 & B2/0083-0084 & Twig & 3985 & 30 & $2576-2463$ & House wall-fall & \\
\hline & BA120863 & B2/0036 & Twig & 3915 & 35 & 2488-2291 & House wall-fall & \\
\hline
\end{tabular}
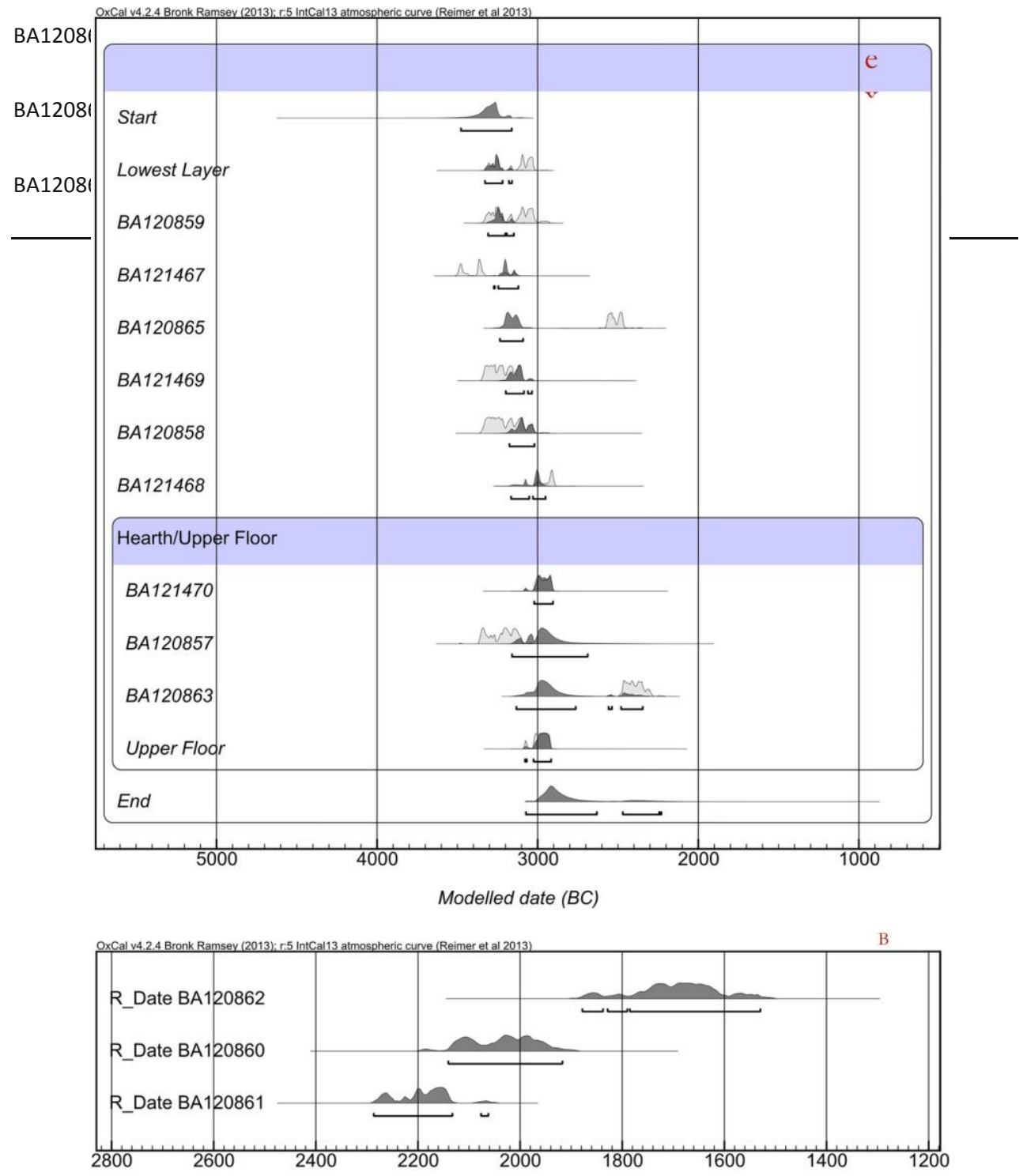


\section{Macrobotany}

House (Zone A)

From the early phase of house use (phase A1), only one seed, identified as Chenopodium sp., was recovered together with a number of parenchyma (Table 2).

Phase $A 2$ is associated with the use of the house. The majority of identifiable plant remains are derived from these features, which include floors, internal pits, and a fireplace with multiple firing events. In distinction from phase A1, charred seeds and plant parts were recovered and identified to genera or families. Those that can be identified to the genus level include Stipa sp./Bromus sp., Cheopodium sp., Luzula sp., Carex sp., Rumex sp., Polygonum sp., Cerastium sp., cf. Achillea sp., and Artemisia sp. (Fig. 7). Apart from those genera, charred seeds belonging to Poaceae, Brassicaceae, Boraginaceae, Rosaceae, Juncaceae, and Asteraceae were recovered. Parenchyma and vitrified plant remains were found from various contexts in this phase (Fig. 8). The parenchyma fragments, not studied in this paper, could have come from various root plants that constituted a part of starch source for Botai's inhabitants.

\section{Outside the house}

Sediments were also floated from this pit cut into the wall fall showing that they were later than the house in Zone A. One unidentifiable charred seed and one parenchyma were recorded. With the exception of two Chenopodium sp. and one Polygonum sp. charred seeds, no other plant seeds were recovered from the external features (i.e., the pits in Zone A external to the house or in Zone B). Only parenchyma and vitrified plant remains were commonly recovered.

Charred seeds recovered from feature test trench E (probably a stove or kiln) include Chenopodium sp. and Polygonum sp. In total, 36 vitrified remains were found in the top dark layer of the kiln.

\section{Phytoliths}

During the phytolith analysis, no difference between protocols was noticed in phytolith abundance. The silica count per slide comprises only up to 10 phytoliths, while most of the slides did not contain any phytoliths at all (Table 3 ). The only silica remains that were present in the slides were amorphous silica fragments that could derive from natural loess deposits or from wood ash (Geis 1973; Osterrieth et al. 2009). 
Table 2 Summary of archaeobotanical remains uncovered at the Botai site

\begin{tabular}{|c|c|c|}
\hline Contexts & Taxa & Seed count \\
\hline \multicolumn{3}{|l|}{ Inside the house (zone A) } \\
\hline \multicolumn{3}{|l|}{ Phase A1 } \\
\hline C. $3500 \mathrm{cal} \mathrm{BC}$ & Chenopodium sp. & 1 \\
\hline Phase A2 & Stipa sp./Bromus sp. & 2 \\
\hline \multirow[t]{12}{*}{ (second half of the 4 th millennium $B C$ ) } & Chenopodium sp. & 19 \\
\hline & Juncaceae & 1 \\
\hline & Luzula sp. & 1 \\
\hline & Carex sp. & 1 \\
\hline & Rumex sp. & 8 \\
\hline & Polygonum sp. & 4 \\
\hline & Cerastium sp. & 1 \\
\hline & Achillea sp. & 4 \\
\hline & Artemisia sp. & 1 \\
\hline & Boraginaceae & 1 \\
\hline & Poaceae & 1 \\
\hline & Rosaceae & 2 \\
\hline & Asteraceae & 1 \\
\hline
\end{tabular}

Outside the house

Domestic pits outside the house

$\begin{array}{ll}\text { Chenopodium sp. } & 7 \\ \text { Polygonum sp. } & 5 \\ \text { Stipa sp./Bromus sp. } & 3 \\ \text { Chenopodium sp. } & 21 \\ \text { Polygonum sp. } & \text { total: } 21\end{array}$

Trench E (Stove)

Polygonum sp.

total: 21 

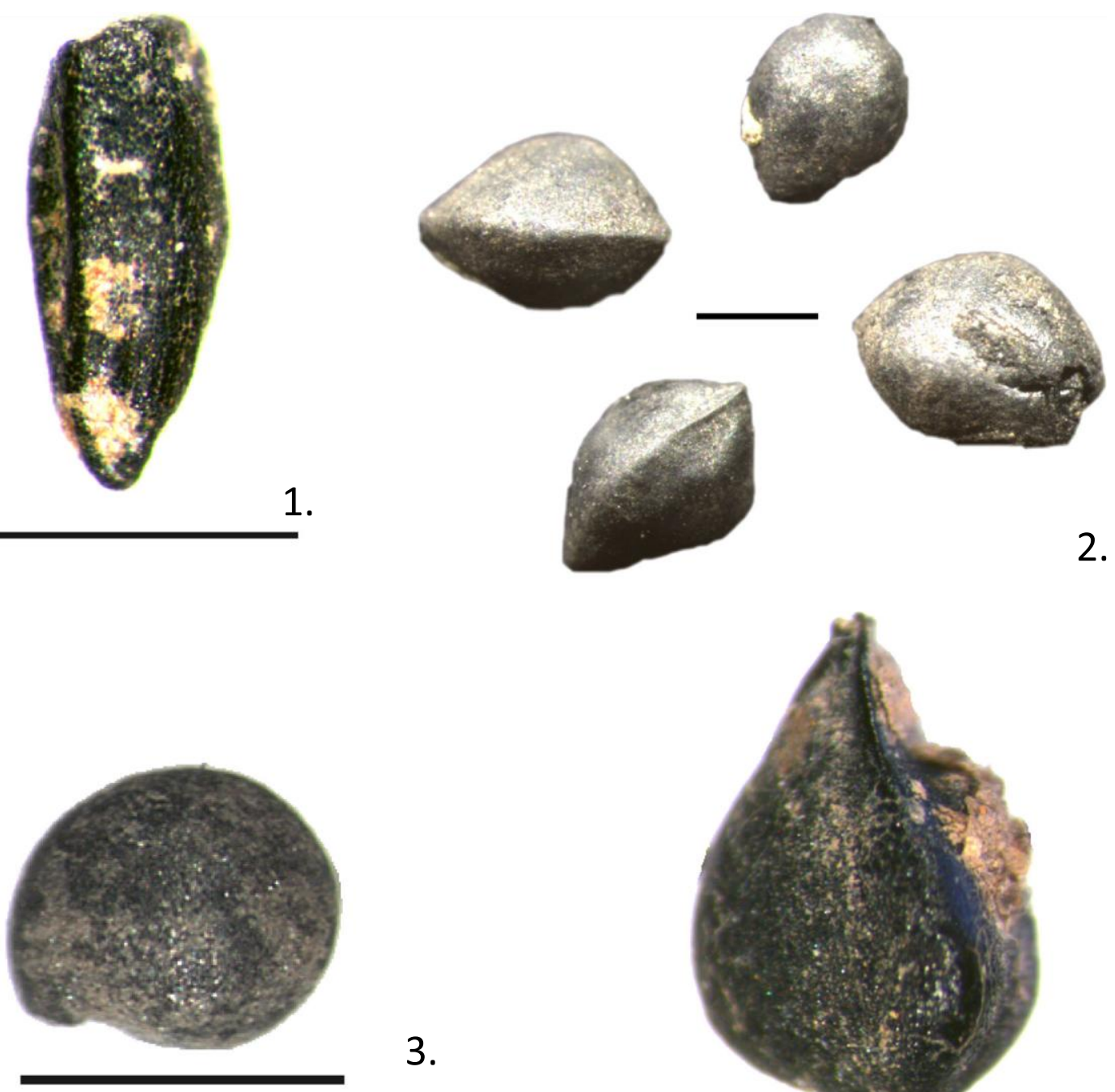

3.

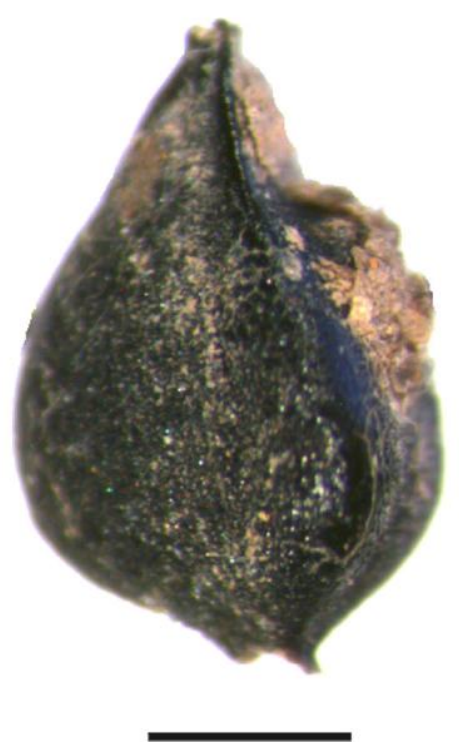

4.

Fig. 7 The most frequently found carbonised seeds of 1 . Achillea sp., 2. Polygonum sp., 3. Chenopodium sp., 4. Rumex sp

The slides that contained the highest phytolith counts were taken from the ash lenses of pit 3 , outside the house, and the buried soils outside the site. Most of the phytoliths identified at Botai come from the leaves of small shrubs (as globular echinate), stems, and leaves of grasses (as rondels, papillae and trapeziform short cells, elongate echinate long cell) (Fig. 9). A few diatom cells were also identified on the slides; these may have arrived with drinking water, or alternatively derived from Pleistocene loess (Fig. 9).

\section{Miliacin}

Miliacin was found at very low concentrations (from 3 to $30 \mathrm{ng} / \mathrm{g}$ ) in all samples analysed and was not accompanied by any other PTME. This lack of other PTMEs is a criterion for attributing P. miliaceum as the source of miliacin (Bossard et al. 2013) (Table 4). The largest concentrations of miliacin were found in one context inside the house (Zone A), the rivercut section (test trench D), and the stove/kiln feature sited away from the pit house (test trench E). Other pentacyclic triterpenes such as friedelin and taraxeryl acetate were also found in the lipid extracts. 


\section{Discussion}

The radiocarbon dating of the excavated pit house is in agreement with the dates of the past excavations of Botai site, showing that the pit house was occupied during the second half of the fourth millennium BC (Anthony and Brown 2011; Baumer 2012). The date of the external (test trench E) stove/ kiln feature located on the edge of the settlement was significantly later than occupation of a pit house. The dates show that the structure could have been built during the end of the third millennium or even the first half of the second millennium BC, and indicate a previously unknown period of use of site's occupation.

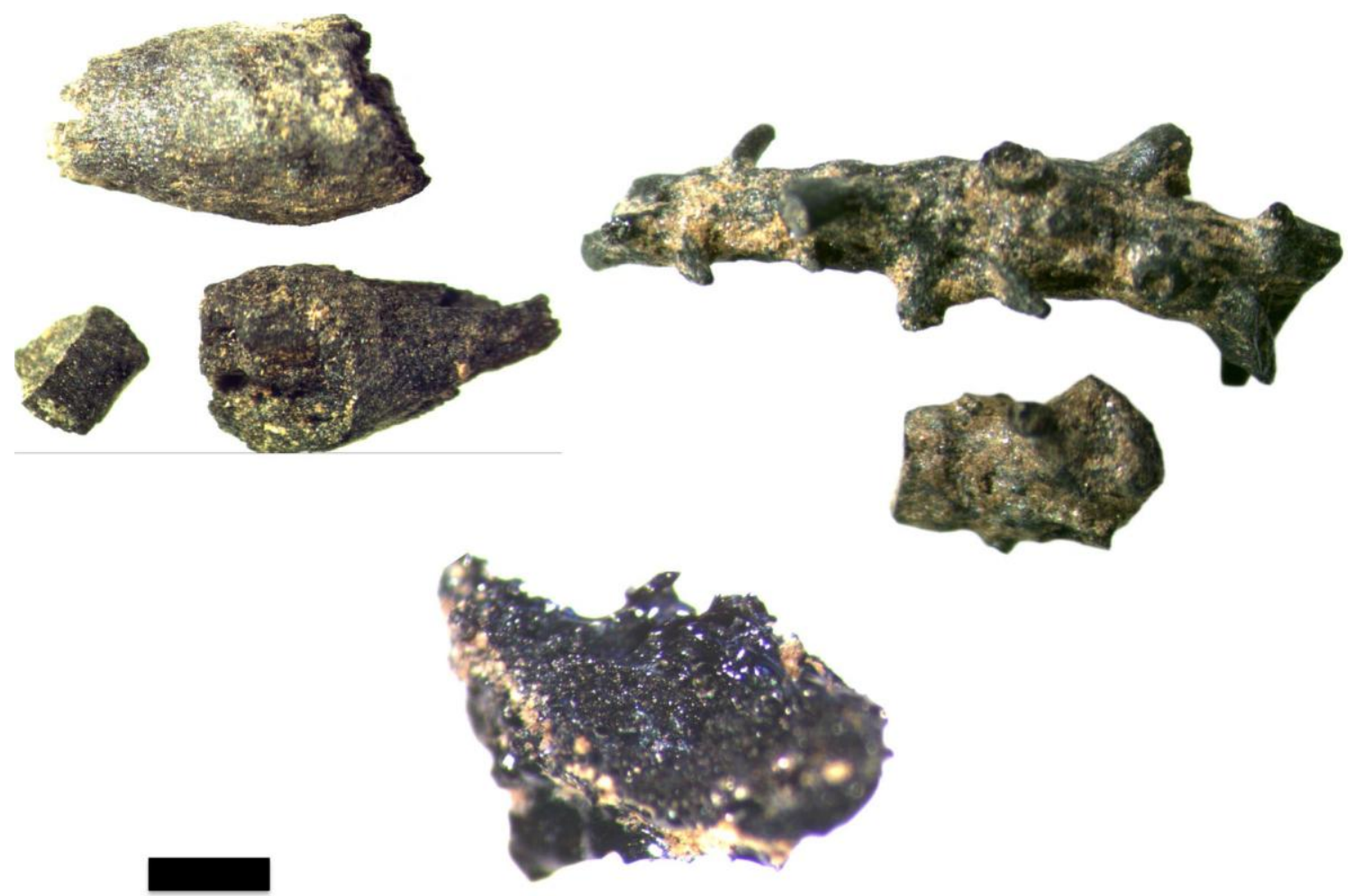

Fig. 8 Grass roots (top left), twigs of brushes (top right) and vitrified plant remain from the house B2 (bottom)

The flotation results of 2006 I of sediment from 50 contexts and associated phytolith analysis data suggest that plant consumption was not a quotidian feature of Botai lifeways. No domesticated plants were identified at the site from macrofossils and phytoliths. The low frequency of seeds from Botai may be due to the nature of combustion and fires at the site. The vitrified plant remains discovered in most contexts show that plants were exposed to high burning temperatures. In order for a plant to become vitrified, it has to burn in temperatures between 700 and $800{ }^{\circ} \mathrm{C}$ (McDonnell 2001), which is beyond that usually attained by wood fires. It has been suggested that high temperatures could have been achieved in burning fatty bones in fires (Beresford-Jones et al. 2010; Marquer et al. 2011).Animal fat has a highheat ofcombustion of $32 \mathrm{~kJ} / \mathrm{g}$, comparable with coal and almost twice that of most woods (De Haan 2008). The high quantity of horse bones shows that the meat was consumed by Botai inhabitants. It is possible to speculate that dripping fat from cooking of horse meat above fires increases in burning temperatures and thus negatively affecting plant preservation. The presence of vitrified plant remains in the stove/kiln of later period than Botai occupation would require different explanation on how such high temperatures were reached.

The low phytolith count in the analysed samples is also not well understood. There are multiple factors that could be accountable for phytolith presence/absence in sediments, that include for example, plant type, climate, soil/ sediment chemistry, and analytical protocol (Strömberg et al. 2018). Previous studies show that the pH could be accountable for the absence of phytoliths in certain sediments; for example, Piperno (1985) reports the absence of phytoliths from shell 
midden sites in Panama where the pH ranged between 8.9 and 9.3. The solubility of non-biogenic silica increases quickly at $\mathrm{pH} 9$ and above; an elevated soil pH may therefore dissolve phytoliths as well (Piperno 1985). The soil pH at Botai varied between 7.9 and 8.8. This environment is rather basic; however, the $\mathrm{pH}$ values seen in Botai should not account for the scarcity of phytoliths. Finally, it can be mentioned that the Botai site is situated on the bed of an ancient Messinian Lake that existed between 7 and 5 million years ago. Due to the intense past oxidation and slow sedimentary processes in the shallow lake, red clay deposits were formed that presently constitute the main sediment type in Botai. According to Strömberg et al. (2018), red beds with abundant clay and organic-rich sediments such as lignites appear to be the least favourable for phytolith preservation.

The macroscopic plant species recovered from Botai consist only of wild plants, dominated by Chenopodium and Polygomum genera plants. Their small quantities preclude inference about whether or not those plants constituted a part of the human diet. Archaeobotanical investigations at slightly later sedentary sites in the Ural region of Russia recovered large quantities of Chenopodium, Amaranthus, and Stipa sp. Species (Popova 2006; Rühl et al. 2015). The Stipa grass, goosefoot, and amaranth species could have well constituted a source of starch for human consumption.

Table 3 Table summarizing the phytolith remains and the readings of the $\mathrm{pH}$ tests. The processed sample size is $5 \mathrm{~g}$

\begin{tabular}{|c|c|c|c|c|c|}
\hline $\begin{array}{l}\text { Sample } \\
\text { number }\end{array}$ & $\begin{array}{l}\text { Context } \\
\text { number }\end{array}$ & Trench/Sq & Description of a context & $\begin{array}{l}\mathrm{pH} \text { test } \\
\text { results }\end{array}$ & $\begin{array}{l}\text { Phytolith count } \\
\text { by } \\
\text { morphotypes }\end{array}$ \\
\hline
\end{tabular}

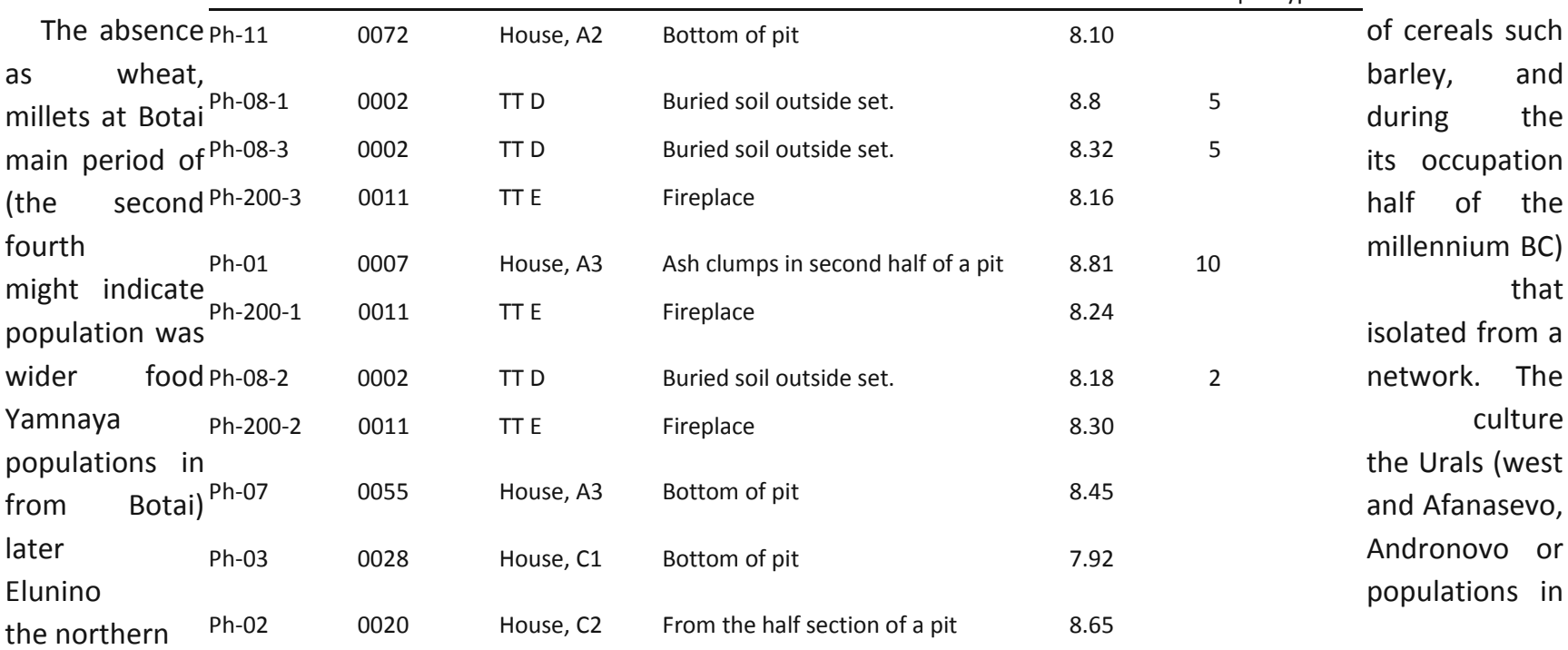

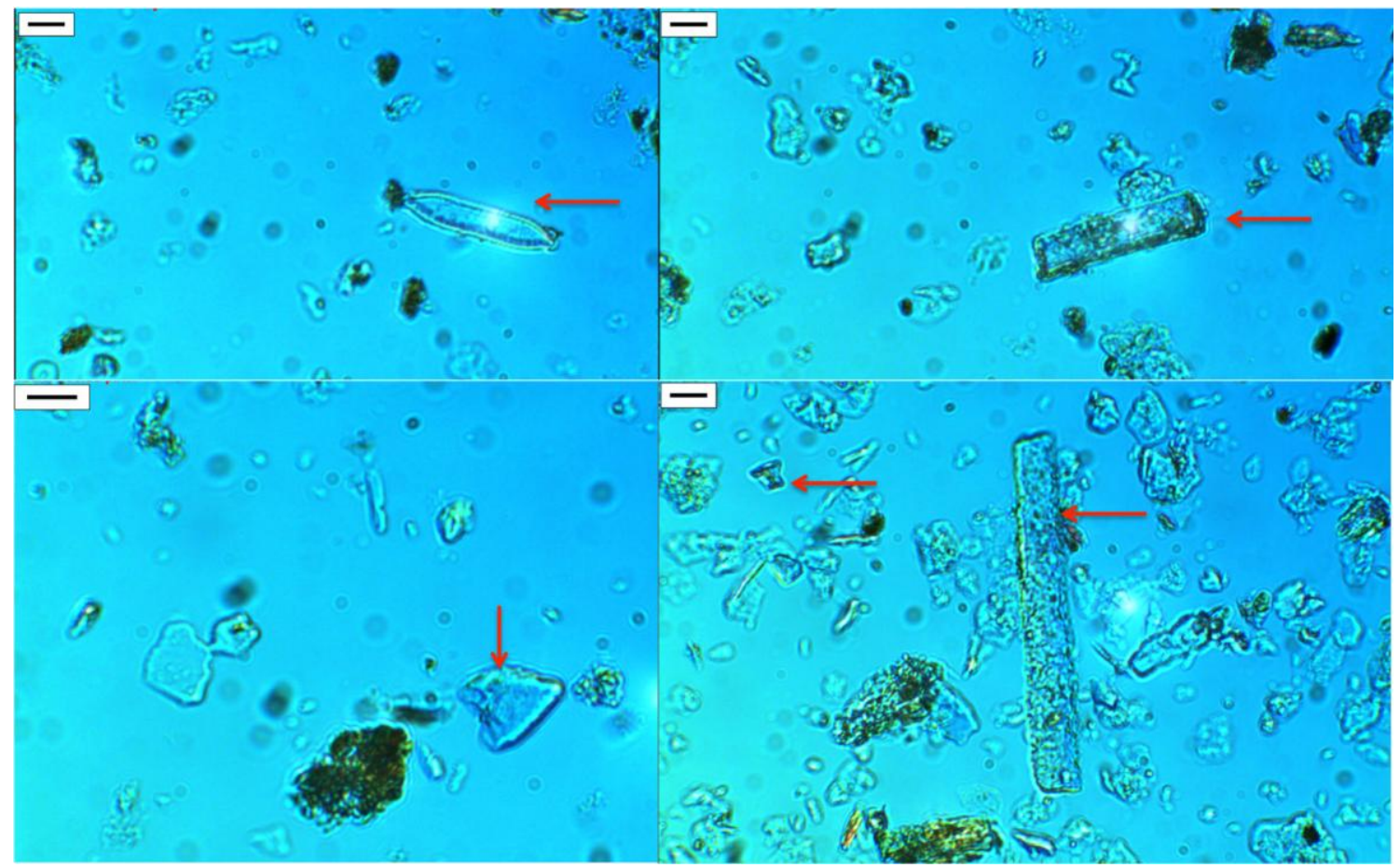

Fig. 9 An example of diatom (top left) and phytoliths found at the Botai site. Scale bars $=10 \mu \mathrm{m}$ 


\begin{tabular}{lll}
\hline Miliacin sample & Amount (ng/g) & $\begin{array}{l}\text { Excavation } \\
\text { area }\end{array}$ \\
\hline BOTAl 11-B003 & 3 & Zone A \\
BOTAl 11-B004T2 & 8 & Zone A \\
BOTAl 11 B002-B20095 & 12 & Zone A, B2 \\
BOTAl 11 B0041-B20057 & 30 & Zone A, B2 \\
BOTAl 11 A2-0042 & 6 & Zone A, A2 \\
BOTAl 11 B200 test E & 23 & Test trench E \\
BOTAl 11 B001-1 test trench D & 5 & Test trench D \\
BOTAl 11 B001-2 test D & 27 & Test trench D \\
BOTAl 11 B20095-B002 & 12 & Zone A, B2 \\
\hline
\end{tabular}

Table 4 Summary of the biomarker results

Steppe regions and in the Altai (east from Botai), practised cattle breeding at least in the later stages of the Botai culture's existence (Anthony 2007; Motuzaite Matuzeviciute et al. 2016). However, despite a few domestic horses, which they possessed for hunting wild horses (the Botai model was similar to reindeer hunter societies further north in Siberia that use reindeer husbandry to control the resource better, without the full set of implications for reindeer use), the Botai inhabitants did not have any domesticated animals of southwest origin, such as sheep, goat, or cattle (Outram et al. 2009). It is possible that our macrobotanical and microbotanical samples are not a representative of the entire site of Botai and of other Botai culture sites. Nevertheless, archaeobotanical studies at other Botai culture sites, such as Marai 1 (Afonin et al. 2017) or Borly (Giedre Motuzaite Matuzeviciute, unpublished data), also did not recover any domesticated plant taxa.

Miliacin found in our samples can reasonably be attributed to Panicum miliaceum because it is not associated to other pentacyclic triterpene methyl ethers (Bossard et al. 2013). The presence of miliacin in soil or sediment samples usually implies that a sufficient biomass of P. miliaceum was present to yield measurable amounts of miliacin. This can only occur if millet was directly grown in the soils sampled, if the surfaces of these soils were used to process millet after harvesting, or if manure with millet remains was used to fertilize the fields (Motuzaite Matuzeviciute et al. 2013b). It is thus of great interest to ascertain when miliacin entered the archaeological sediments. Miliacin concentrations are low in all of our samples. In three samples, values in the order of $30 \mathrm{ng} / \mathrm{g}$ are recorded, which are the highest among these low values. One of these is the isolated stove/kiln structure (test trench E), dated to 2290 to $1530 \mathrm{cal} \mathrm{BC}$; the other concentration is the undated palaeosol alongside the river and within the Botai period house in Zone A. In the absence of macrofossil evidence from the Botai period and the position of the archaeological sediments within an active soil horizon, the possibility of vertical movement of molecular biomarkers, as well as laboratory contamination, cannot be discarded. An alternative explanation could be the presence of grass species that also contain small quantities of miliacin, such as wild Panicum or Pennisetum. Nevertheless, this rather tantalizing evidence suggests an episode or episodes of millet cultivation or usage over the site that likely relates to a relatively late stage of use of the site, possibly represented in the Trench E stove/kiln and the Trench D palaeosol. The low levels of miliacin associated withZone A may well be intrusive as downward movement of material through the sediment was shown from the Bayesian modelling (see SOM 1).

Finally, it is important to note that despite flotation of thousands of litres of sediment, our archaeobotanical research is coming from contexts that might not reflect the typical plant contribution to diet. Further research is needed to enrich our understanding on the starch food component for prehistoric inhabitants of the steppe. 


\section{Conclusions}

An extensive archaeobotanical investigation was conducted at the Botai site aiming to investigate plant use among the population of Botai. In total, 2006 I of sediment was floated from 50 contexts (43 features) but this resulted in no evidence of domesticated plant remains. The recovered plants consisted mainly of wood charcoal and charred seeds of Chenopodium sp. (goosefoots), Rumex sp. (docks), Carex sp. (sedge), Polygonum sp. (knotweed), and Stipa sp./Bromus sp.; species that were identified inside the house could have come as roofing, fuel, and fodder or could been used as food. Achillea sp. (yarrow) and Artemisia sp. have both aromatic and disinfectantproperties(Abad et al. 2012) and could havebeenusedfor medicinal purposes or as bedding. The presence of fragments of parenchyma could suggest that the people of Botai consumed roots or tubers containing starch alongside horse meat.

The phytolith study of 18 contexts, including fireplaces, house floors, and possible agricultural soil profiles did not show any evidence of domesticated grasses. Instead, the phytoliths belonged to small shrubs, stems, and leaves of grasses.

The radiocarbon dates (16 in total) derived from the seasonal plant stems and twigs have shown that the analysed contexts started to function between 3550 and $3030 \mathrm{cal} \mathrm{BC}$, and ended between 3080 and $2670 \mathrm{cal} \mathrm{BC}$. A separate feature (stove or kiln), excavated in test trench E, would seem to be younger, around 2000 cal BC.

Archaeobotanical data are not suggestive of a quotidian use of food plants by the Botai inhabitants. The findings are consistent with a diet that was heavily dependent upon animal products with a very minor contribution of wild plant foods. Current data show that the Botai community was not part of a wider food network with agricultural communities from neighbouring regions.

The presences of miliacin in the context of the absence of other PTMEs would suggest that at some point in time, Panicum miliaceum was grown or used in the Botai landscape. This may well correspond to the period of use of the riveredge palaeosol and Trench E stove/kiln, the latter of which was dated to the second millennium BC. While the occurrence of small quantities of miliacin in association with Botai period house sediments is tantalizing, the parsimonious explanation is currently that those quantities may relate to vertical movement through an active soil, from a later episode of activity.

Acknowledgements

We would like to thank the archaeological expedition team in Kazakhstan. In addition, we would like to express gratitude to Claude Le Milbeau and Rachel Boscardin (Institut des Sciences de la Terre d'Orléans) for samples preparation in miliacin analyses, and Carla Lancelotti and Jennifer Bates for helping with phytolith extraction.

Funding information This study was financially supported by the ERC advanced investigator award (to MKJ) GA249642 BFood Globalization in Prehistory^ and the National Science Foundation, under grant 1826727, BThe origins and spread of millet cultivation^ (PI: XL) The work of EL was supported by the TwoRains project which was funded by the European Research Council (ERC) under the European Union's Horizon 2020 research and innovation programme (grant agreement number 648609).

\section{References}

Abad MJ, Bedoya LM, Apaza L, Bermejo P (2012) The Artemisia L. genus: a review of bioactive essential oils. Molecules 17(3):2542-2566

Afonin AS, Ivanov SN, Ryabogina NE (2017) Prirodnoe okruzhenie naseleniya Priishimya na rubezhe bronzovogo i zheleznogo vekov (po dannym paleobotanicheskikh issledovanii gorodischa Marai-1). Vestnik Arkheologii, Antropologii I etnografii 3(38):162-175

Ananyevskaya E, Aytqaly A, Beisenov A, Dmitriev E, Garbaras A, Kukushkin I, Loman V, Sapolaite J, Usmanova E, Varfolomeev V (2017) Early indicators to C4 plant consumption in central Kazakhstan during the Final Bronze Age and Early Iron Age based on stable isotope analysis of human and animal bone collagen. Archaeol Res Asia 15:157-173

Anderberg A (1994) Atlas of the seeds and small fruits of the NorthwestEurope plant species (Sweden, Norway, Denmark, East Fennoscandia, and Iceland) with morphological description, vol 4. Risbergs Tryckeri AB, Stockholm 
Anthony D (1997) Current thoughts on the domestication of the horse in Asia. South Asian Studies 13(1):315-318

Anthony D (2007) The horse, the wheel, and language: how Bronze-Age riders from the Eurasian steppes shaped the modern world. Princeton University Press, Woodstock

Anthony DW, Brown DR (2011) The secondary products revolution, horse-riding, and mounted warfare. J World Prehist 24(2-3):131- 160

Anthony DW, Brown D, Brown E, Goodman A, Kokhlov A, Kosintsev P, Kuznetsov P, Mochalov O, Murphy E, Peterson D, Pike-Tay A, Popova L, Rosen A, Russel N, Weisskopf A (2005) The Samara Valley Project: Late Bronze Age economy and ritual in the Russian steppes. Eurasia Antiqua 11:395-417

Baumer C (2012) The history of Central Asia, vol 1. I.B.Tauris \& Co Ltd, New York

Benecke N, Von Den Driesch A (2003) Horse exploitation in the Kazakh Steppes during the Eneolithic and Bronze Age. In: Levine MA, Renfrew AC, Boyle K (eds) Prehistoric steppe adaptation and the horse. McDonald Institute Monographs for Archaeological Research, Cambridge, pp 69-82

Beresford-Jones DG, Johnson K, Pullen AG, Pryor AJE, Svoboda J, Jones MK (2010) Burning wood or burning bone? A reconsideration of flotation evidence from Upper Palaeolithic (Gravettian) sites in the Moravian Corridor. J Archaeol Sci 37(11):2799-2811

Berggren G (1994) Atlas of the seeds and small fruits of the NorthwestEurope plant species (Sweden, Norway, Denmark, East Fennoscandia, and Iceland) with morphological description, vol 2, 3. Risbergs Tryckeri AB, Stockholm

Betts A, Jia PW, Dodson J (2013) The origins of wheat in China and potential pathways for its introduction: a review. Quat Int 348:158-168

Boivin N, Fuller DQ, Crowther A (2012) Old World globalization and the Columbian exchange: comparison and contrast. World Archaeol 44(3):452-469

Bossard N, Jacob J, Le Milbeau C, Sauze J, Terwilliger V, Poissonnier B, Vergès E (2013) Distribution of miliacin (olean-18-en-3ß-ol methyl ether) and related compounds in broomcorn millet (Panicum miliaceum) and other reputed sources: implications for the use of sedimentary miliacin as a tracer of millet. Org Geochem 63:48-55

Bronk Ramsey C (2009) Dealing with outliers and offsets in radiocarbon dating. Radiocarbon. 51(3):1023-1045

Bronk Ramsey, C. 2013. OxCal 4.2. [Online]. Available from: http://c14. arch.ox.ac.uk/oxcal

Cappers RTJ, Bekker RM, Jans JEA (2006) Digitale zadenatlas van Nederland (Digital Seed Atlas of the Netherlands). Barkhuis Publishing and Gronigen University Library, Groningen

Chang C, Benecke N, Grigoriev F, Rosen A, Tourtellotte P (2003) Iron age society and chronology in South-east Kazakhstan. Antiquity 77(296):298-312 de Barros Damgaard, P, Martiniano R, Kamm J, Moreno-Mayar JV, Kroonen G, Peyrot M, Barjamovic G, Rasmussen S,

Zacho C, Baimukhanov N (2018) The first horse herders and the impact of early Bronze Age steppe expansions into Asia. Science 360: eaar7711. https://doi.org/10.1126/science.aar7711

De Haan JD (2008) Fires and bodies. In: Schmidt CW, Symes SA (eds) The analysis of burned human remains. Academic Press, London, pp 1-15

Doumani PN, Frachetti MD, Beardmore R, Schmaus TM, Spengler RN, Mar'yashev AN (2015) Burial ritual, agriculture, and craft production among Bronze Age pastoralists at Tasbas (Kazakhstan). Archaeol Res Asia 1:17-32

Filipović D, Meadows J, Wiethold J, Jahns S, Bittmann F, Kirleis W (2018) Before and after: millet cultivation and the transformation of prehistoric crop production in northern Germany. Antiquity 92(365)

Frachetti MD, Spengler RN, Fritz GJ, Mar'yashev AN (2010) Earliest direct evidence for broomcorn millet and wheat in the central Eurasian steppe region. Antiquity 84(326):993-1010

Frachetti MD, Smith CE, Traub CM, Williams T (2017) Nomadic ecology shaped the highland geography of Asia's Silk Roads. Nature 543(7644):193-198

French CAI (2003) Geoarchaeology in action: studies in soil micromorphology and landscape evolution. Routledge, London

Gaunitz C, Fages A, Hanghøj K, Albrechtsen A, Khan N, Schubert M, Seguin-Orlando A, Owens IJ, Felkel S, Bignon-Lau O (2018) Ancient genomes revisit the ancestry of domestic and Przewalski's horses. Science 360(6384):111-114

Geis JW (1973) Biogenic silica in selected species of deciduous angiosperms. Soil Sci 116(2):113-130

Hermes TR, Frachetti MD, Doumani Dupuy PN, Mar'yashev A, Nebel A, Makarewicz CA, (2019) Early integration of pastoralism and millet cultivation in Bronze Age Eurasia. Proceedings of the Royal Society B: Biological Sciences 286 (1910):20191273

Hunt HV, Vander Linden M, Liu X, Motuzaite-Matuzeviciute G, Colledge S, Jones MK (2008) Millets across Eurasia: chronology and context of early records of the genera Panicum and Setaria from archaeological sites in the Old World. Veg Hist Archaeobotany 17: 5-18

Jacob J, Disnar J-R, Boussafir M, Albuquerque ALS, Sifeddine A, Turcq B (2005) Pentacyclic triterpene methyl ethers in recent lacustrine sediments (Lagoa do Caçó, Brazil). Org Geochem 36(3):449-461

Janik L (2002) Wandering weed: the journey of buckwheat (Fagopyrum sp.) as an indicator of human movement in Eurasia. In: Boyle K, Renfrew C, Levine M (eds) Ancient interactions: east and west in Eurasia. McDonald institute for archaeological research, Cambridge, $\mathrm{pp}$ 299-307

Jones MK (2004) Between fertile crescents: minor grain crops and agricultural origins. In: Jones MK (ed) Traces of ancestry: studies in honour of Colin Renfrew. McDonald Institute for Archaeological Research, Cambridge, pp 127-135

Jones M, Hunt H, Lightfoot E, Lister D, Liu X, Motuzaite Matuzeviciute G (2011) Food globalization in prehistory. World Archaeol 43(4): 665675

Jones, MK., Hunt, H., Kneale,C. Lightfoot, E., Lister, D., Liu, X. and Motuzaite-Matuzeviciute, G. (2016) Food globalisation in prehistory: the agrarian foundations of an interconnected continent. J Br Acad 4: 73-87

Kislenko A, Tatarintseva N (1999) The eastern Ural steppe an the end of the Stone Age. In: Levine M, Rassamakin Y, Kislenko A, Tatarintseva N (eds) Late prehistoric exploration of the Eurasian steppe. McDonald Institute for Archaeological Research, Cambridge, pp 183-213 
Krivtsova-Grakova OA (1947) Alekseevskoe poselenie i mogilnik. TGIM, Nauka, Alma-Ata

Kučera L, Peška J, Fojtík P, Barták P, Kučerová P, Pavelka J, Komárková V, Beneš J, Polcerová L, Králík M (2019) First direct evidence of broomcorn millet (Panicum miliaceum) in Central Europe. Archaeol Anthropol SciArchaeol Anthropol Sci 11:4221-4227. https://doi. org/10.1007/s12520-019-00798-4

Lebedeva EY (2005) Arkheobotanika i izuchenie zemledeliya epokhi bronzy v Vostochnoi Evrope. OPUS: Mezhdistsiplinarnye issledovaniya v arkheologii 4:50-64

Levine MA (1999) Botai and the origins of horse domestication. J Anthropol Archaeol 18(1):29-78

Lister DL, Jones H, Oliveira HR, Petrie CA, Liu X, Cockram J, Kneale CJ, Kovaleva O, Jones MK (2018) Barley heads east: genetic analyses reveal routes of spread through diverse Eurasian landscapes. PLoS One 13(7):e0196652

Liu X, Lister DL, Zhao Z, Staff RA, Jones PJ, Zhou L, Pokharia AK, Petrie CA, Pathak A, Motuzaite Matuzeviciute G, Lu H (2016) The virtues of small grain size: potential pathways to a distinguishing feature of Asian wheats. Quat Int 426:107-119

Liu X, Lister D, Zhao Z, Petrie CA, Zeng X, Jones, P.J., Staff RA, Pokharia AK, Bates J, Singh RN, Weber SA, Motuzaite Matuzeviciute G, Dong G, Li H, Lü H, Jiang H, Wang J, Ma J, Tian D, Jin G, Zhou L, Wu X, Jones MK (2017) Journey to the east: wheat and barley took different pathways, and faced different environmental challenges, on the way to prehistoric China. Plos1 13 (12):1-16

Liu X, Motuzaite Matuzeviciute G, Hunt H (2018) From a fertile idea to a fertile arc: the origins of broomcorn millet 15 years on. In: Liu X, Lightfoot E, Hunt $\mathrm{H}$ (eds) Far from the hearth. Essays in Honour of Martin K. Jones. McDonald Institute Monograph, Cambridge, pp 155176

Liu X, Jones PJ, Motuzaite Matuzeviciute G, Hunt HV, Lister DL, An T, Przelomska N, Kneale CJ, Zhao Z, Jones MK (2019) From ecological opportunism to multi-cropping: mapping food globalisation in prehistory. Quat Sci Rev 206:21-28

Long T, Leipe C, Jin G, Wagner M, Guo R, Schröder O, Tarasov PE (2018) The early history of wheat in China from 14 C dating and Bayesian chronological modelling. Nature plants 4(5):272-279

Marquer L, Lebreton V, Otto T, Valladas H, Haesaerts P, Messager E, Nuzhnyi D, Péan S (2011) Charcoal scarcity in Epigravettian settlements with mammoth bone dwellings: the taphonomic evidence from Mezhyrich (Ukraine). J Archaeol Sci 39:109-120

McDonnell J (2001) Pyrotechnology. In: Brothwell DR, Pollard AM (eds) Handbook of Archaeological Sciences. Wiley, Chichester, pp $493-506$

Miller NF, Spengler RN, Frachetti M (2016) Millet cultivation across Eurasia: origins, spread, and the influence of seasonal climate. The Holocene 26(10):1566-1575

Motuzaite Matuzeviciute G, Hunt HV, Jones MK (2009) Multiple sources for Neolithic European agriculture: geographical origins of early domesticates in Moldova and Ukraine. In: Dolukhanov P, Sarson GR, Shukurov AM (eds) The East European plain on the eve of agriculture, BAR international series, vol S1964. Archaeopress, Oxford, pp 53-64

Motuzaite Matuzeviciute G, Staff RA, Hunt HV, Liu X, Jones MK (2013a) The early chronology of broomcorn millet (Panicum miliaceum) in Europe. Antiquity 87(338):1073-1085

Motuzaite Matuzeviciute G, Jacob J, Telizhenko S, Jones MK (2013b) Miliacin in palaeosols from an Early Iron Age in Ukraine reveal in situ cultivation of broomcorn millet. Archaeol Anthropol Sci 8(1): 43-50

Motuzaite Matuzeviciute G, Lightfoot E, O'Connell T, Voyakin D, Liu X, Loman V, Svyatko S, Usmanova E, Jones M (2015) The extent of cereal cultivation among the Bronze Age to Turkic period societies of Kazakhstan determined using stable isotope analysis of bone collagen. $J$ Archaeol Sci 59:23-34

Motuzaite Matuzeviciute G, Kiryushin YF, Rakhimzhanova SZ, Svyatko S, Tishkin AA, O'Connell TC (2016) Climatic or dietary change? Stable isotope analysis of Neolithic-Bronze Age populations from the Upper Ob and Tobol River basins. The Holocene 26(10):1711- 1721

Murphy EM, Schulting R, Beer N, Chistov Y, Kasparov A, Pshenitsyna M (2013) Iron age pastoral nomadism and agriculture in the Eastern Eurasian steppe: implications from dental palaeopathology and stable carbon and nitrogen isotopes. J Archaeol Sci 40:2547-2560

Olsen S (2000) The secular and sacred roles of dogs at Botai, North Kazakhstan. In: Crockford SJ (ed) Dogs through time: an archaeological perspective. Proceedings of the 1st ICAZ symposium on the history of the domestic dog; Eighth Congress of the International Council for Archaeozoology (ICAZ98), August 23-29, 1998, Victoria, BC, Canada, BAR International Series vol 889. British Archaeological Reports Ltd., pp 71-92

Olsen S (2003) The exploitation of horses at Botai, Kazakhstan. In: Levine M, Renfrew C, Boyle K (eds) Prehistoric steppe adaptation and the horse. McDonald institute for archaeological research, Oxford, pp 83-103

Osterrieth M, Madella M, Zurro D, Fernanda Alvarez M (2009) Taphonomical aspects of silica phytoliths in the loess sediments of the Argentinean Pampas. Quat Int 193(1):70-79

Outram A, Stear N, Bendrey R, Olsen S, Kasparov A, Zaibert V, Thorpe N, Evershed R (2009) The earliest horse harnessing and milking. Science 323(5919):1332-1335

Piperno DR (1985) Phytolith taphonomy and distributions in archeological sediments from Panama. J Archaeol Sci 12(4):247-267

Popova LM (2006) Political pastures: navigating the Steppe in the Middle Volga Region (Russia) during the Bronze Age. University of Chicago, Department of Anthropology

Reimer PJ, Bard E, Bayliss A, Beck JW, Blackwell PG, Ramsey CB, Buck CE, Cheng H, Edwards RL, Friedrich M (2013) IntCal13 and Marine13 radiocarbon age calibration curves 0-50,000 years cal BP. Radiocarbon 55(4):1869-1887

Rosen A (2001) Phytolith evidence for agropastoral economies in the Scythian period of southern Kazakhstan. In: Meunier JD, Colin F (eds) The Phytoliths: applications in earth science and human history. A. A. Balkema Publisher, Leiden, pp 183-198

Rosen AM, Chang C, Grigoriev FP (2000) Palaeoenvironments and economy of Iron Age Saka-Wusun agro-pastoralists in southeastern Kazakhstan. Antiquity 74(285):611-623 
Rühl L, Herbig C, Stobbe A (2015) Archaeobotanical analysis of plant use at Kamennyi Ambar, a Bronze Age fortified settlement of the Sintashta culture in the southern Trans-Urals steppe, Russia. Veg Hist Archaeobotany 24(3):413-426

Ryabogina NE, Ivanov SN (2011) Ancient agriculture in Western Siberia: problems of argumentation, paleoethnobotanic methods, and analysis of data. Archaeol Ethnol Anthropol Eurasia 39(4):96-106

Shishlina N, Sevastyanov V, Kuznetsova O (2018) Seasonal practices of prehistoric pastoralists from the south of the Russian plain based on the isotope data of modern and archaeological animal bones and plants. J Archaeol Sci Rep 21:1247-1258

Spengler RN, Chang C, Tourtellotte PA (2013) Agricultural production in the Central Asian mountains: Tuzusai, Kazakhstan (410-150 B.C.). J Field Archaeol 38(1):68-85

Spengler RN, Frachetti MD, Doumani P, Rouse L, Cerasetti B, Bullion E, Mar'yashev AN (2014a) Early agriculture and crop transmission among Bronze Age mobile pastoralists of Central Asia. Proc R Soc 281:20133382

Spengler RN, Cerasetti B, Tengberg M, Cattani M, Rouse LM (2014b) Agriculturalists and pastoralists: Bronze Age economy of the Murghab alluvial fan, southern Central Asia. Veg Hist Archaeobotany 23(6):805-820

Spengler RN, Ryabogina N, Tarasov PE, Wagner M (2016) The spread of agriculture into northern Central Asia: timing, pathways, and environmental feedbacks. The Holocene 26(10):1527-1540

Stobbe A, Joop Kalis A (2012) Archaeobotanical investigations in the Trans-Urals (Siberia): the vegetation history. In: Bebermeier W, Hebenstreit R, Kaiser E, Krause J (eds) Landscape archaeology. Conference (LAC 2012). eTopoi Journal for Ancient Studies, Special volume 3, pp 297-303

Strömberg CAE, Dunn RE, Crifò C, Harris EB (2018) Phytoliths in paleoecology: analytical considerations, current use, and future directions. In: Croft DA, Su DF, Simpson SW (eds) Methods in paleoecology: reconstructing Cenozoic terrestrial environments and ecological communities. Springer, Cham, pp 233-285

Svyatko SV, Schulting RJ, Mallory J, Murphy EM, Reimer PJ, Khartanovich VI, Chistov YK, Sablin MV (2013) Stable isotope dietary analysis of prehistoric populations from the Minusinsk Basin, Southern Siberia, Russia: a new chronological framework for the introduction of millet to the eastern Eurasian steppe. J Archaeol Sci 40(11):3936-3945

Tarasov PE, Williams JW, Kaplan JO, Österle H, Kuznetsova TV, Wagner M (2012) Environmental change in the temperate grasslands and steppe. In: Matthews JA, Bartlein PJ, Briffa KR et al (eds) The SAGE handbook of environmental change: human impacts and responses, vol 2. Los Angeles, CA, SAGE, pp 215-244

Valamoti SM (2013) Millet, the late comer: on the tracks of Panicum miliaceum in prehistoric Greece. Archaeol Anthropol Sci 8:51-63

Zaibert VF (1981) Issledovaniya v Severnom Kazakhstane.

Arkheologicheskie otkrytya 1980 goda:435-436

Zaibert VF (1985) Poselenie Botai i zadachi issledovaniya eneolita Severnogo Kazakhstana. In: Zaibert VF, Zdanovich SY (eds) Eneolit i bronzovyi vek Uralo-Irtyshskovo mezhdurechya: mezhvuzovskii sbornik. Chelyabinsk gos. universitet, Chelyabinsk, pp 3-17

Zaibert VF (1993) Eneolit Uralo-Irtyshskogo Mezhdurechya. Nauka, Petropavlovsk

Zaibert VF, Tyulebaev A, Zhadorozhnyi A, Kulakov Y (2007) Tainy drevney stepi. Kokshetau Universitet, Kokshetau 